ljtihad: Jurnal Wacana Hukum Islam dan Kemanusiaan

Vol. 21, No. 1 (2021), pp. 21-37, doi : 10.18326/ijtihad.v21i1.21-37

\title{
The accuracy of online-based prayer times applications
}

\section{Encep Abdul Rojak, Ilham Mujahid, and Muhammad Yunus}

Universitas Islam Bandung

E-mail:abdrrozaq19@gmail.com, ilhammujahidounawan@gmail.com,yunus_rambe@yahoo.co.id

DOI: 10.18326/ijtihad.v21i1.21-37

There are various types of prayer times that Muslims refer to on a daily basis. Specifically, there are offline and online prayer times as well as traditional and modern prayer times. Online prayer times that can be accessed from a mobile phone in forms such as android-based applications, online websites, and Google applications. The purpose of this study is to investigate the accuracy of onlinebased prayer times applications and seek for the possible consistency across these applications. This study employs a qualitative approach and a descriptive data analysis. The data collection is conducted through observations, literature study, and in-depth interviews. This study indicates different degree of deviations among online-based prayer times applications, in which Google applications show the most deviation among the others. This study suggests that Muslims refer to online applications recommended by the Ministry of Religious Affairs of Indonesia.

Terdapat jadwal shalat yang beragam di masyarakat Muslim. Untuk setiap daerahnya, terdapat jadwal shalat offline dan online, juga jadwal tradisional dan modern. Jadwal online berupa aplikasi android, website dan google. Tujuan penelitian ini untuk mengetahui akurasi jadwal shalat online dan membandingkan antara satu aplikasi dengan yang lainnya, sehingga didapatkan aplikasi yang direkomendasikan untuk digunakan karena tergolong akurat. Pada penelitian metode penelitian yang digunakan adalah kualitatif dengan analisis data menggunakan deskripsi. Pengumpulan data menggunakan teknik observasi langsung kepada aplikasi jadwal shalat online, kajian literatur yang berkaitan dengan jadwal shalat, dan wawancara mendalam. Hasil penelitian ini menunjukkan bahwa setelah dibandingkan dengan jadwal shalat resmi dari kementrian agama republic Indonesia terdapat selisih data antara beberapa aplikasi jadwal shalat online. Keunikan dari penelitian adalah kita mengetahui bahwa tidak bisa merujuk jadwal shalat online secara umum, namun rujuklah aplikasi jadwal shalat yang direkomendasikan, yaitu dari Kementrian Agama RI.

Keywords: Prayer time; accuracy; online applications 
Ijtihad: Jurnal Wacana Hukum Islam dan Kemanusiaan, Volume 21, No. 1, Juni 2021: 21-37

\section{Introduction}

Various types of prayer times emerge, and these can be found in both offline and online forms. Consequently, it is becoming easier for Muslims to find references regarding prayer times. Online-based prayer times applications are among popular time references used by Muslims throughout the world. These include android-based applications, website-based applications, and Google applications. However, the accuracy and validity of such online applications are often questionable since they somehow show different prayer times.

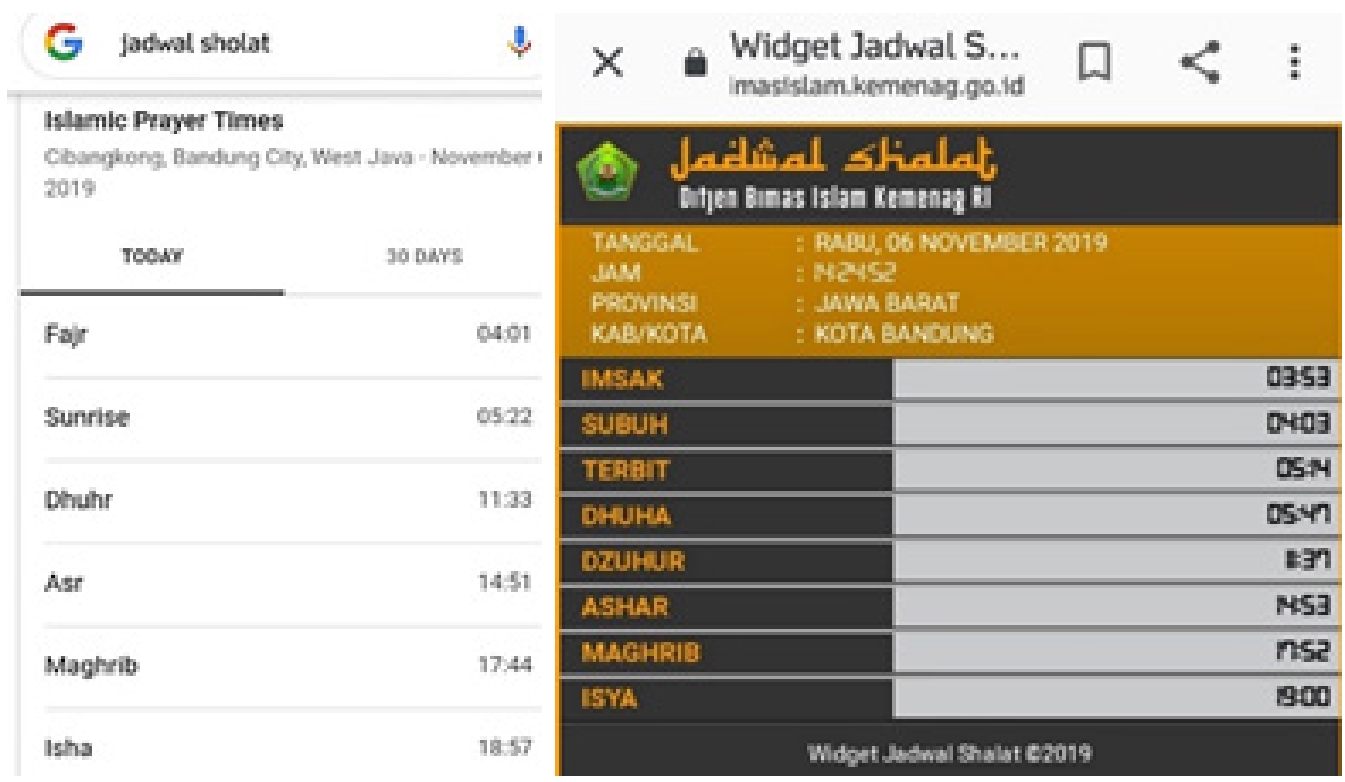

Figure 1. Prayer times in two different online applications

Figure 1 presents two online applications which display prayer times in Bandung city on Wednesday, November $6^{\text {th }}, 2019$. The left column represents a Google application, while the right one represents an online application developed by the Ministry of Religious Affairs. When compared, it is apparent that there are disparities of prayer times in these two online applications. Detailed comparison is presented in the table below.

Table 1. Comparison of two online-based prayer times applications 


\begin{tabular}{cccr}
\hline $\begin{array}{c}\text { Names of } \\
\text { prayer }\end{array}$ & $\begin{array}{c}\text { Prayer Times by } \\
\text { Google in WIT* }\end{array}$ & $\begin{array}{c}\text { Prayer Times by the Ministry of } \\
\text { Religious Affairs in WIT* }\end{array}$ & Disparities \\
\hline Fajr & $04.01 \mathrm{AM}$ & $04.03 \mathrm{AM}$ & 2 minutes \\
Dhuhr & $11.33 \mathrm{AM}$ & $11.37 \mathrm{AM}$ & 4 minutes \\
Asr & $14.51 \mathrm{PM}$ & $14.53 \mathrm{PM}$ & 2 minutes \\
Maghrib & $17.44 \mathrm{PM}$ & $17.52 \mathrm{PM}$ & 8 minutes \\
Isha & $18.57 \mathrm{PM}$ & $19.00 \mathrm{PM}$ & 3 minutes \\
\hline
\end{tabular}

*WIT refers to Western Indonesia Time

Disparities are apparent in the five prayer times in these two online applications. For example, a two-minute gap occurs during Fajr prayer and Asr prayer. Meanwhile, there are three-minute and four-minute gaps between Isha and Dhuhr prayers, respectively. The biggest time difference is found in Maghrib prayer with an eight-minute gap between these online applications. In addition to these time differences, all prayer times in the Google application clearly precede the times stated in the Ministry of Religious Affairs' online application.

Previous studies about prayer times were conducted with different focuses of discussions. A study entitled "The Implementation of the Middle Coordinate of Regencies and Cities for Measuring Prayer Times" was carried out to explore the exact geographical coordinates that could be used as the basis for determining prayer times throughout a particular region. This study was necessary to develop a unitary prayer times system that could be implemented in regencies or cities that had large areas. This study resulted in two main findings. First, the implementation of the middle coordinate as the basis of measurement covered not only an area where the middle coordinate was located. Further, similar prayer times were also apparent in areas in which their coordinates deviated 0,5 degrees from the middle coordinate either to the west or to the east. Thus, the middle coordinate was preferably used as it likely covered large areas that belonged to certain region. Second, in term of geographical range, the use of the middle coordinate was sufficient to cover a region regarding the unitary prayer times system. As such, adding extra minutes (ikbtijat) to an area that was not located exactly on the middle coordinate was unnecessary (Ardliansyah, 2017).

Another study entitled "Using Altitude Correction Data to Determine Prayer Times in 
Bandung City" was conducted by Rojak, Hayatudin and Yunus (2017). Through a qualitative approach, this study found that to determine the beginning of Maghrib prayer in Bandung City, data which consisted of altitude correction ought to be incorporated when measuring prayer times. These data were largely overlooked by prayer astronomers, which resulted in a substantial inaccuracy. This study recommended that altitude correction data were taken into account, especially for areas in Bandung City which were located 50 meters above the sea level (Rojak, Hayatudin and Yunus, 2017).

Principally, prayer times are based on the sun's positions towards the earth. Consequently, prayer times are measured locally according to geographical data in which an area is located. Different geographical locations thus cause different prayer times throughout the Earth. A geographical positioning system (hereafter GPS) installed in a smartphone can help locate geographical data of a given area accurately. For instance, Ma'almusalli is a smartphonebased application that uses GPS data to determine prayer times in certain locations. A study which explores the accuracy of Ma'almusalli even when it is used in an offline state entitled “Offline Prayer Times System” was carried out by (Hafez, A., \& Zeki, 2016).

Departing from this background, there is a lack of study which specifically investigates the accuracy of online-based prayer times applications. Given the importance of these applications for Muslims, this study is aimed at scrutinizing the accuracy of these applications and providing input for the development of the applications.

\section{Methodology}

This study employed a qualitative approach to investigate the data regarding online-based prayer times applications. Data collection was conducted through observation, literature review, and in-depth interviews. That is, the data from different applications were gathered and then compared one another. Additionally, seminal literature on astronomy was closely scrutinized while interviews with astronomers were also carried out. Collected data were further analyzed through a descriptive analysis method.

\section{The basis of prayer times in the Islamic scriptures}

Statements which discuss prayer times are written in the Quran and the Hadith. These 
statements describe five mandatory prayer times that each Muslim must perform. The Quran Surah an-Nisa verse 103 states:

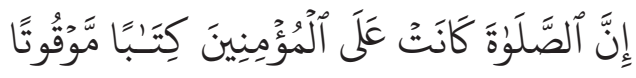

".... Verily, for all believers, prayer is indeed a sacred duty linked to particular times [of day]."

In addition, it is stated in the Quran Surah al-Isra verse 78 that:

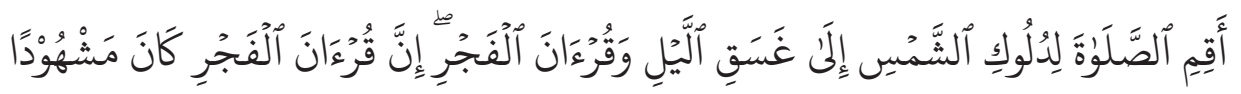

"Establish regular prayers at the sun's decline till the darkness of the night and the morning prayer and reading: for the prayer and reading in the morning carry their testimony."

In addition to these Quranic verses, the Prophet Muhammad, peace be upon him, has provided more detailed prayer times in his Hadith. As narrated by (An-Naisaburi, 2010), the Prophet Muhammad stated:

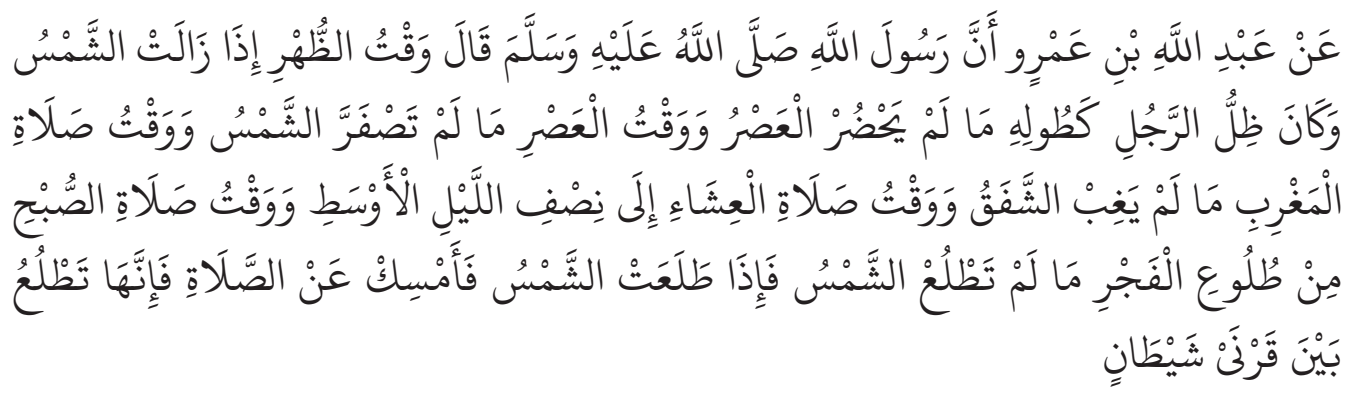

"'Abdullah bin 'Amr reported that the Messenger of Allah said: The time of the noon prayer is when the sun passes the meridian and a man's shadow is the same (length) as his height, (and it lasts) as long as the time for the afternoon prayer has not come; the time for the afternoon prayer is as long as the sun has not become pale; the time of the evening prayer is as long as the twilight has not ended; the time of the night prayer is up to the middle of the average night and the time of the morning prayer is from the appearance of dawn, as long as the sun has not risen; but when the sun rises, refrain from prayer for it rises between the horns of the devil." (p. 210)

Based on the descriptions stated in the Quran and the Hadith, it is understood that the times of the five prayers have been determined accordingly. In particular, the sun's 
Ijtihad: Jurnal Wacana Hukum Islam dan Kemanusiaan, Volume 21, No. 1, Juni 2021: 21-37

positions are used as the primary references in determining the beginning and the end of each prayer time. For example, Maghrib prayer must be performed after the sun sets, while Fajr prayer starts after the dawn and ends before the sun rises. Rojak, Hayatudin and Yunus (2017) details the basic principles of prayer times as stated in the Quran and the Hadith in the following descriptions:

1. Dhuhr prayer starts when the sun passes the meridian and is located slightly to the west. It ends when the shadow of an object, at an angle of 90 degrees to the ground, is the same length as its height. However, according to the Hanafi's school of thought, Dhuhr prayer ends when the length of the shadow is twice the height of its object.

2. Asr prayer begins when the shadow of an object, at an angle of 90 degrees to the ground, is the same length as its height. While according to the Hanafi's school of thought, it begins when the length of the shadow is twice the height of its object. Asr prayer finishes before the sun's color turns into yellow. In an emergency situation, Asr prayer finishes before the sun sets or, in a different opinion, when the sun exactly sets.

3. The beginning of Maghrib prayer is when the sun sets. In other words, the sun's circumference cannot be seen in the west horizon. It ends when the twilight, a red reflection of the sun light on the earth's atmosphere, disappears.

4. In general, Isha prayer starts when the twilight disappears, and it ends in the middle of the average night. However, there are several different opinions regarding the end of Isha prayer. According to the Shafi'i's school of thought in their initial statements (qaul qadim), Isha prayer ends in the last of the third part of the night with an extra time until the dawn. While according to the Hanafi's school of thought, the end of Isha prayer occurs just before the dawn. In addition to these two opinions, other Islamic scholars suggest that Isha prayer finishes in the midnight (Amri, 2014).

5. Fajr prayer begins when the dawn appears and finishes when the sun rises. The dawn in here refers to the reflection of the sun light on the the earth's atmosphere that appears in the east horizon. This reflection largely permeates the horizon (Noor, Rosyadi and Hamdani, 2018).

\section{The fiqh of astronomy in relation to prayer times}


It is apparent that the sun is the object that becomes the basis for measuring prayer times. Based on the sun's coordinate positions towards the earth, digital prayer times are developed along with other elements (Yudhana, Fadlil and Rosad, 2019). The sun is a star that produces its own light through a chemical process that takes place in its core. In its core, fusion reactions occur in which four atoms of hydrogen fuse into a single atom of helium. With a strong pressure in the core and an enormous temperature of more than 15 million K, the fusion reactions continue to produce light (Gautama, 2010).

The position of the sun towards the earth impacts many aspects of life, in which one of them is the world time zone. As the position of the sun shifts towards the earth, the time in an area also shifts gradually. In other words, times are different from one area to another, depending on the sun's position towards certain areas (Rojak, 2021). As such, the sun's position also causes different areas to experience different prayer times. For example, prayer times in areas that are exposed to the sun will be different from the ones that are not exposed to the sun (Azhari, 2007). This different exposure occurs because, in addition to the movement of the earth rotating the sun, the earth is a sphere.

\section{The position of the sun towards prayer times}

In the Hadith, Prophet Muhammad indicated that prayer times were based on the position of the sun. Muslim astronomers define the position of the sun as the unit of measurement that represents the altitude of the sun or the distance of the sun from the zenith. The altitude of the sun is specifically calculated using the sun angle equation and is converted into units of times. In other words, the position of the sun in a certain altitude equals to a specific time in a given area (Ali, 1997). Through this calculation, prayer times in certain areas can be determined.

Primarily, there are two astronomical data that are used to determine prayer times, namely the altitude of the sun and the hour angle of the sun. Data from these two aspects should be calculated prior to determining prayer times (Niri et al., 2012).

a. The altitude of the sun (b)

The altitude of the sun in the sky can be calculated by measuring its distance from the horizon skirt towards the zenith and the nadir. The scale of measurement used in this calculation ranges from $0^{\circ}$ to $90^{\circ}$. Other term used in calculating the altitude of an object 
in the sky is zenith distance. There are differences between the altitude of the sun and zenith distance when they are used to determine prayer times. To determine prayer times, the altitude of the sun is measured from its horizon on the ground level until it passes the vertical skirts, both the zenith and the nadir, of the horizon. Meanwhile, zenith distance measures the distance of the sun from the zenith.

A positive value $(+)$ is given to indicate that the sun's altitude is above the horizon. Meanwhile, a negative value (-) is used to show that sun's altitude is below the horizon. The positive and the negative values mean differently when using the sun's altitude as the basis for measuring prayer times. The positive value indicates that the sun can be visually observed, while the negative value indicates that the sun in invisible (Khazin, 2005). Figure 2 illustrates the altitude of the sun in details.

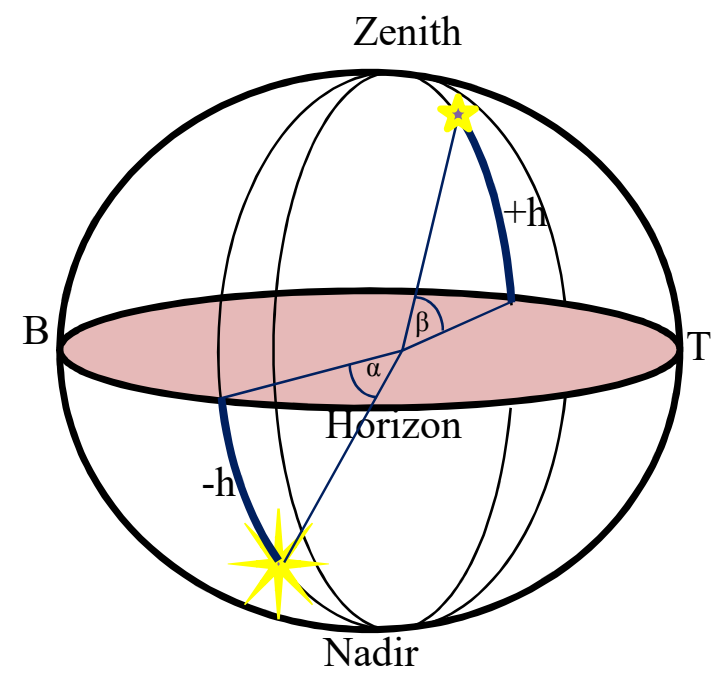

Figure 2. The altitude of the sun measure from the horizon skirts. The positive value occurs when the sun's altitude is relative to the zenith. The negative value is given when the sun's altitude is relative to the nadir.

Based on the altitude of the sun, prayer times are determined. In other words, the altitude of the sun observed from certain areas determines which prayer times that take place in those areas (Mohamoud, 2007). Furthermore, different sun's altitudes will also determine 
different prayers that must be performed. For example, the time for Asr prayer is distinct from Maghrib prayer due to different sun's altitudes observed in the horizon. The data about the altitude of the sun is collected by the Ministry of Religious Affairs to determine prayer times in Indonesia. For instance, according to the Ministry of Religious Affairs, Dhuhr prayer starts when the altitude of the sun passes the zenith slightly to the west. Meanwhile, the beginning of prayers such as Maghrib, Isha, and Fajr is determined when the altitude of the sun is $-1^{\circ},-18^{\circ}$, and $-20^{\circ}$ towards the nadir, respectively (Islam, 2010). Muslim astronomers, however, have dissenting opinions about these degrees (Ilyas, 1984).

Online and offline prayer times are both based on a similar measurement system, that is using the altitude of the sun as the basis of the measurement (Hafez, A., \& Zeki, 2016). The data about the sun's altitudes are carefully to make sure the accuracy of prayer times. Figure 3 illustrates how to measure the time for Asr prayer.

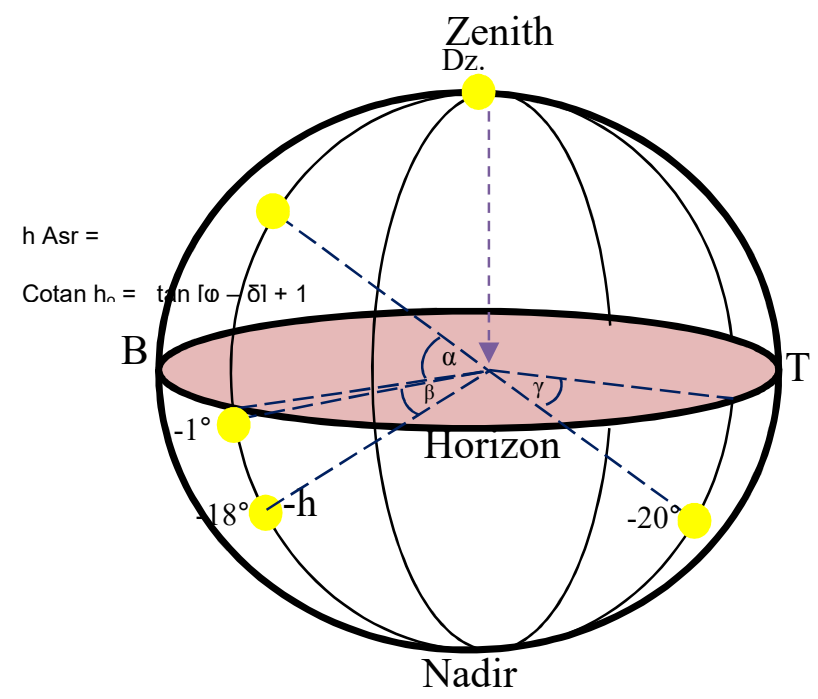

Figure 3. Measuring the altitude of the sun to determine the beginning of Asr prayer.

As seen in figure 3, the beginning of Asr prayer is not represented by a constant value. This occurs because the time for Asr prayer emerges from the combination of two shadows, which are the shadow of the beginning of Dhuhr prayer and the shadow of a stick whose 
length is the same as the stick. In other words, the combination of these two shadows creates the value where the sun's altitude indicates the beginning of Asr prayer (Hadi, 2009). A more detailed description of how Asr prayer is determined can be seen in the figure 4 below.

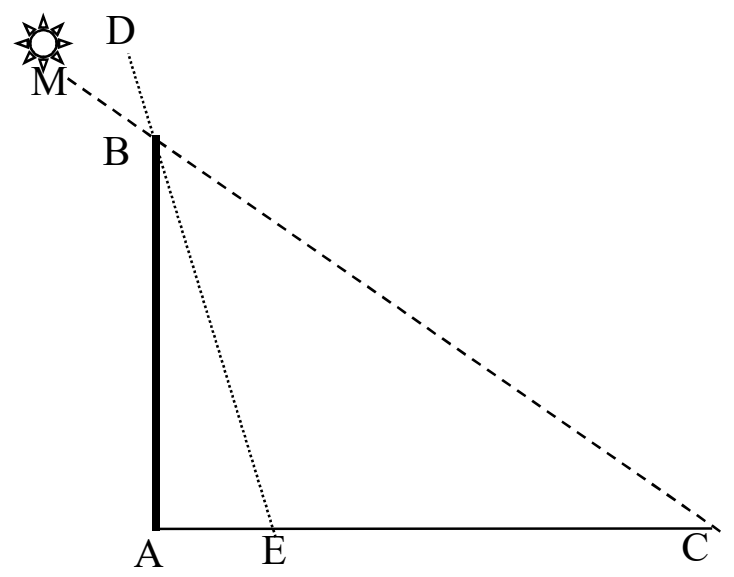

Figure 4. Calculating the time of Asr prayer. AB line represents a standing stick. DBE line represents the position of the sun in the beginning of Dhuhr prayer. AE line represents the length of Dhuhr times. MBC line represents the position of the sun in the beginning of Asr prayer. EC line represents the length of Asr times.

DBE line illustrated above represents the position of the sun which slightly passes the zenith towards the west. This position indicates the beginning of Dhuhr prayer. In this position, as illustrated by AE line, an upright shadow of a standing object emerges. The length of the shadow can be calculated using the following equation: $\tan [\varphi-\delta]$. On the other hand, the length of EC line (shadow) is equal to the length of the standing object ( $\mathrm{AB}$ line), in which trigonometry it has the value of 1 (Rojak, 2021). As such, the equation for calculating the beginning of Asr prayer is the length of shadow in the beginning of Dhuhr prayer (AE line) plus the length of EC line (Ali, 1997). In other words, it is Cotan $h_{\mathrm{o}}=\tan [\varphi-\delta]+1^{1}$.

\footnotetext{
${ }^{1} \mathbf{h}=$ the altitude of the sun; $\delta=$ the declination of the sun; $\varphi=$ latitude; $1=$ equation
} 
With this equation, measuring the altitude of the sun to determine the beginning of Asr prayer can be done mathematically without having to observe the sun directly. This equation can also be programmed into digital devices such as computers and calculators. As such, researchers can use these devices conveniently when determining prayer times.

\section{b. The hour angle of the sun ( $t)$}

In astronomy, the hour angle of the sun refers to the angular distance of the sun measured from the celestial poles to the position of the sun. In other words, it is an angle between celestial poles, the meridian plane, and the declination plane that passes the sun (Khazin, 2005). The hour angle of the sun is denoted as a small $t$, in which the value of the $t$ is converted into global times system (Ray, 2012).

The hour angle of the sun ranges from $0^{\circ}$ to $180^{\circ}$. The starting point of this angle lies on the zenith, that is when there is a certain distance between the sun and the zenith. Meanwhile, the end point of this angle is on the nadir. The hour angle of the sun is further categorized into two values, which are negative $(-)$ and positive $(+)$ values. Negative values are given when the sun is observed in the east meridian, while positive values are given when the sun is in the west meridian. Figure 5 illustrates how the hour angle is measured.

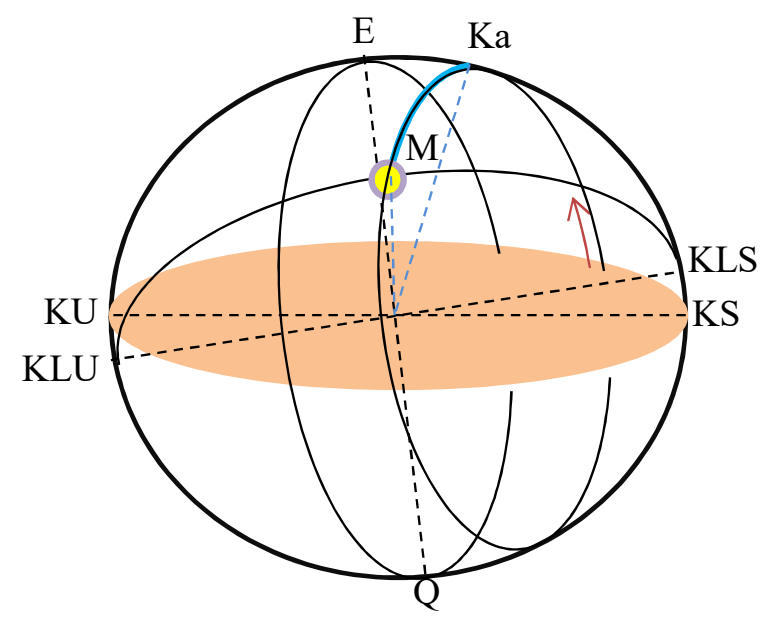

Figure 5. EQ line represents the equator; $\mathrm{M}$ is the sun; KLS is the south celestial pole; KS is the south pole; KLU is the north celestial pole; KU is the north pole; KaM line is the hour angle of the sun. 
To calculate the value of the hour angle of the sun, there are three aspects that must be incorporated into an equation. First is the latitude of an area. The second and the third aspects are respectively the declination of the sun and the altitude of the sun. The equation of this calculation is: $\operatorname{Cos} \mathrm{t}=\operatorname{Sin} \mathrm{h} / \operatorname{Cos} \varphi / \operatorname{Cos} \delta-\operatorname{Tan} \varphi \times \operatorname{Tan} \delta^{2}($ Khazin, 2007).

\section{The accuracy of online-based prayer times}

There are two types of online-based prayer times. The first is web browser-based prayer times and the other is application-based prayer times. Both types of prayer times are easily accessed by Muslims at their fingertips.

\section{Web browser-based prayer times}

Keywords inserted in a web browser substantially influence the results of a search. It is apparent that the search produce results that are based on a rating scheme. Consequently, the results are not always accurate. In the context of searching for prayer times, selecting the right keywords will influence the accuracy of prayer times.

The researchers in this study mitigated several keywords for searching prayer times via web browsers. These include:

1. "Jadwal Shalat" (prayer times) - when typing this keyword in the browser, the top results were a website managed by the Ministry of Religious Affairs and Jadwalshalat.org.

2. "Jadwal Shalat Online" (online prayer times) - the top results were www.jadwalsholat. org, jadwalsholat.pkpu.or.id, and bimasislam.kemenag.go.id.

3. "Jadwal Shalat Update" (updated prayer times) - the top results were www.jadwalsholat. org, jadwalsholat.pkpu.or.id, and bimasislam.kemenag.go.id.

4. "Jadwal Sholat" (with an 'o' letter) - the top results were a website managed by the Ministry of Religious Affairs and Jadwalshalat.org.

5. "Jadwal Sholat Aplikasi Online" (Online-based prayer times application) - the top results were bimasislam.kemenag.go.id, www.jadwalsholat.org, jadwalsholat.pkpu.or.id, republika.co.id, and muslimpro.com.

\footnotetext{
${ }^{2} \mathbf{t}=$ the hour angle of the sun; $\mathbf{h}=$ the altitude of the sun; $\varphi=$ latitude; $\boldsymbol{\delta}=$ the declination of the sun
} 
It has been mentioned previously that prayer times provided by the Google search engine were not accurate compared to prayer times issued by the Ministry of Religious Affairs. Alternatively, it is important to use an appropriate keyword to search for authoritative websites that provide reliable prayer times. From our observation, we recommend the following keywords: jadwal shalat online, jadwal shalat update, and jadwal shalat aplikasi online. These keywords direct us to authoritative online sources as mentioned above.

\section{The calculation of prayer times on online systems}

Online prayer times are developed according to certain data and algorithm that are programmed into online systems. The equations used to calculate the position of the sun towards the earth become the basis of the algorithm. While anyone can use these equations to create their own online prayer times, it is imperative that they coordinate with the authority such as the Ministry of Religious Affairs to make sure the accuracy of data regarding prayer times (interview with Mulyawan, 2020). For example, an online application by Google claims in its website that it uses data from the Ministry of Religious Affairs as the main reference. However, it is found that the developers of this website never made an official request to the Ministry of Religious Affairs to use its data (interview with Fahmi, 2020).

Although this Google-based application claims that it refers to data from the Ministry of Religious Affairs, its prayer times are substantially different from the ones developed by the Ministry of Religious Affairs (see figure 6). A 3 to 7-minute difference is found in the two applications for all of the five prayer times. While the difference might be small, but this impacts Muslims' activities greatly. For example, the difference in the Maghrib prayer can cause confusion when Muslims are about to break their fast. Thus, it is important that online applications, such as the one developed by Google, coordinate with the authority to maintain the accuracy of prayer times (interview with Supriatna, 2020). 


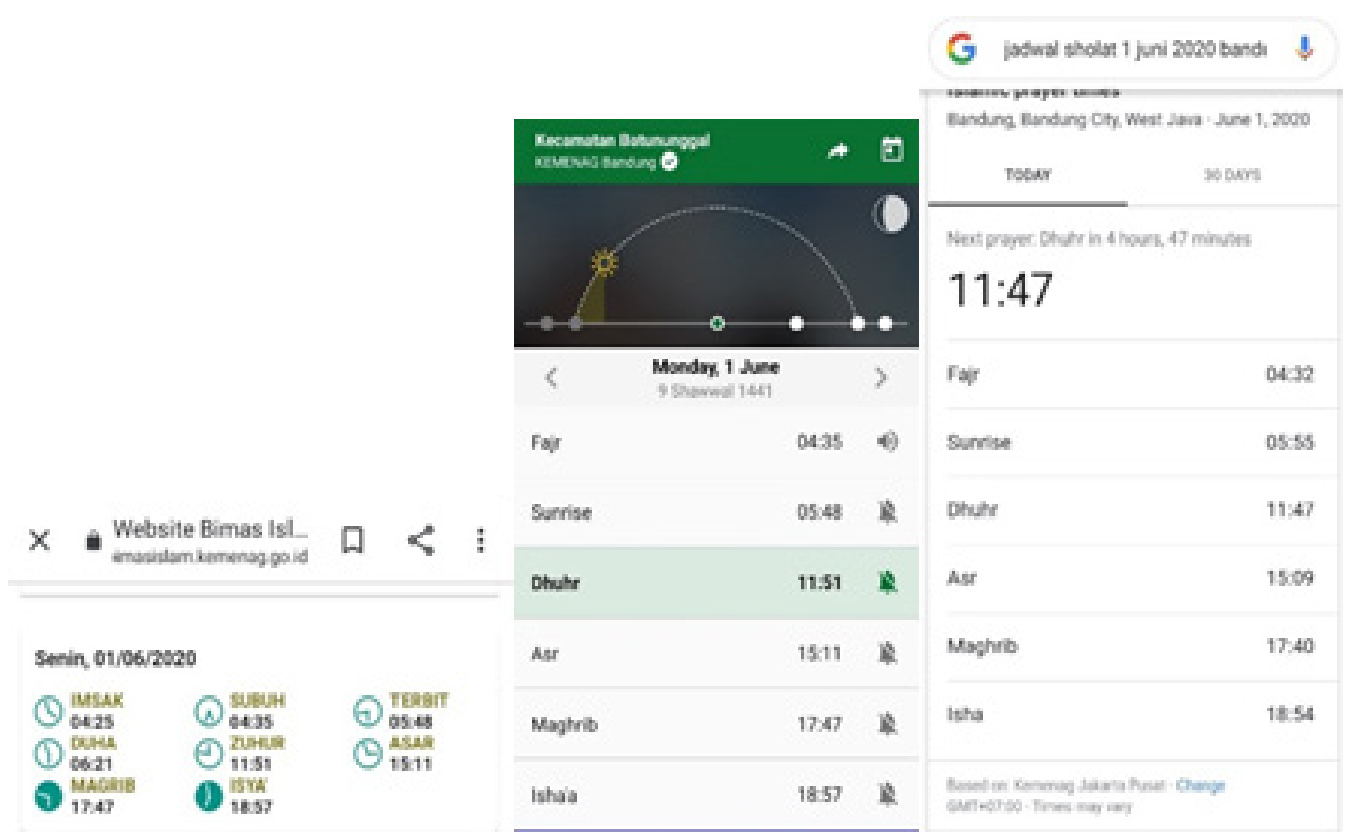

Figure 6. Prayer times shown by three different online applications.

Unlike the Google-based application, there is an online application which is developed based on a certain algorithm that gathers information of prayer times from multiple sources. As seen in figure 7 , this application provides not only prayer times from one source but also prayer times from multiple sources which represent religious officials around the world. In addition, this application also displays which criteria used when measuring the prayer times in a given area.

In general, criteria that are used to measure both offline and online prayer times are as follows:

1. Prayer times are determined by measuring the position of the sun towards the earth.

2. The yearly movement of the sun towards the earth can reach up to $23,5^{\circ}$ as observed from the north to the south.

3. Specific criteria for each prayer time include:

a. Fajr prayer: the position of the sun is at the altitude of $-20^{\circ}$ under the horizon. at this position, the reflection of the sun light on the the earth's atmosphere appears in 
the east horizon.

b. Dhuhr prayer: the sun passes the meridian and is located slightly to the west.

c. Asr prayer: According to Maliki, Shafi'i, and Hambali's schools of thought, Asr prayer begins when the shadow of an object, at an angle of 90 degrees to the ground, is the same length or a little bit longer as its height. While according to the Hanafi's school of thought, it begins when the length of the shadow is twice the height of its object.

d. Maghrib prayer: the sun's circumference cannot be seen in the west horizon.

e. Isha prayer: it starts when the twilight disappears or when the position of the sun is at $-18^{\circ}$ from the horizon.

4. Data taken for measuring prayer times accurately are calculated through certain trigonometric equations.

\section{The comparison of prayer times}

Table 2 below compares online prayer times applications that are popular for Muslims in Indonesia. This comparison specifically discusses prayer times in Bandung, West Java, on June $1^{\text {st }}, 2020$.

Table 2. Comparison of Prayer Times on June 1 ${ }^{\text {st }}, 2020$, in Bandung

\begin{tabular}{cccc}
\hline Names of Prayer & The Ministry of Religious Affairs & Google & Muslim Pro \\
\hline Fajr & $04: 35 \mathrm{AM}$ & $04: 32 \mathrm{AM}$ & $04: 35 \mathrm{AM}$ \\
Dhuhr & $11: 51 \mathrm{AM}$ & $11: 47 \mathrm{AM}$ & $11: 51 \mathrm{AM}$ \\
Asr & $15: 11 \mathrm{PM}$ & $15: 09 \mathrm{PM}$ & $15: 11 \mathrm{PM}$ \\
Maghrib & $17: 47 \mathrm{PM}$ & $17: 40 \mathrm{PM}$ & $17: 47 \mathrm{PM}$ \\
Isha & $18: 57 \mathrm{PM}$ & $18: 54 \mathrm{PM}$ & $18: 57 \mathrm{PM}$ \\
\hline
\end{tabular}

From the table, it is apparent that prayer times from Google are all different from prayer times measured by the Ministry of Religious Affairs and Muslim Pro. The differences range from 2 to 7 minutes, which are quite significance. It can be said that prayer times from Google might be as accurate as the one issued by the Ministry of Religious Affairs and Muslim Pro. 
Ijtihad: Jurnal Wacana Hukum Islam dan Kemanusiaan, Volume 21, No. 1, Juni 2021: 21-37

\section{Conclusion}

Online-based prayer times applications are not all accurate. For example, Google application, which displays prayer times from other unofficial websites, shows inaccurate prayer times compared to other official applications. Online applications developed by local officials are consistent with the application developed by the Ministry of Religious Affairs in terms of the accuracy. To help find accurate prayer times on the internet, it is imperative to use certain keywords such as jadwal shalat online, jadwal shalat update, and jadwal shalat aplikasi online. These keywords direct us to authoritative online applications whose prayer times are similar one another. This in turn indicates the accuracy of prayer times issued by them.

\section{Bibliography}

Ali, M. S. (1997) Ilmu Falak. Jakarta: Raja Grafindo Persada.

Amri, T. (2014) 'halat dalam perspektif syar'i', Asy-Syari'ah, 16(3).

An-Naisaburi, A. a.-H. M. b. a.-H. a.-Q. (2010) Shabih Muslim. Beirut: Maktabah Fayyadh.

Ardliansyah, M. F. (2017) 'Implementasi titik koordinat tengah kabupaten atau kota dalam perhitungan jadwal waktu salat', Al-Abkam, 27(2), pp. 213-240.

Azhari, S. (2007) Ilmu falak perjumpaan khazanah Muslim dan sains modern. Yogyakarta: Suara Muhammadiyah.

Gautama, S. E. (2010) Astronomi dan astrofisika. Makassar: Makassar Press.

Hadi, H. D. H. (2009) Sains untuk kesempurnaan ibadah. Yogyakarta: Prima Pustaka.

Hafez, A., \& Zeki, A. M. (2016) 'Offline prayer times system', Journal of Advanced Science and Engineering Research, 6(2), pp. 1-6.

Ilyas, M. (1984) A modern guide to astronomical calculation of Islamic calender, times, and qibla. Kuala Lumpur: Berita Publishing.

Islam, D. B. M. (2010) Almanak hisab rukyat. Jakarta: Kementerian Agama RI.

Khazin, M. (2005) Kamus ilmu falak. Yogyakarta: Buana Pustaka.

Khazin, M. (2007) Ilmu falak dalam teori dan praktek. Yogyakarta: Buana Pustaka.

Mohamoud (2007) 'Tracing the shadow: Mathematical calculation of prayer times using spherical trigonometry', Middle-East Journal of Scientific Research, 25(8), pp. 1650-1663. 
Niri, M. A. et al. (2012) 'Astronomical determinations for the beginning prayer time of Isha', Middle-East Journal of Scientific Research, 12(1), pp. 101-107.

Noor, L. A. H., Rosyadi, F. F. and Hamdani, S. (2018) 'The dawn sky brightness observations in the preliminary Shubuh prayer time determination', QIJIS: Qudus International Journal of Islamic Studies, 6(1), pp. 25-38.

Ray, S. (2012) 'Calculation of sun position and tracking the path of sun for a particular geographical location', International Journal of Emerging Technology and Advanced Engineering, 2(9), pp. 81-84.

Rojak, E. A. (2021) Ilmu falak hisab pendekatan Microsoft Excel. Jakarta: Kencana.

Rojak, E. A., Hayatudin, A. and Yunus, M. (2017) 'Koreksi ketinggian tempat terhadap fikih waktu salat: Analisis jadwal waktu salat Kota Bandung, Al-Ahkam, 27(2), pp. 241-266.

Yudhana, A., Fadlil, A. and Rosad, S. (2019) 'Jadwal sholat digital menggunakan metode ephemeris berdasarkan titik koordinat smartphone', IT Journal Research and Development (ITJRD), 3(2), pp. 30-43.

\section{Interview}

Fahmi, I., 12 Oktober 2020

Mulyawan, A.S., 7 January 2020

Supriyatna E., 23 Januari 2020 
